\title{
A Collaborative Cloud Service Platform for Realizing Sustainable Make-To-Order Apparel Supply Chain
}

\author{
Ke Ma ${ }^{1,2,3,4}$, Lichuan Wang ${ }^{1, *}$ and Yan Chen ${ }^{1}$ \\ 1 Department of Textile and Clothing Engineering, Soochow University, Suzhou 215021, China; \\ ke.ma@ensait.fr (K.M.); yanchen@suda.edu.cn (Y.C.) \\ 2 GEMTEX (GEnie des Matériaux TEXtile), ENSAIT (Ecole Nationale Supérieure des Arts et Industries Textiles), \\ 59100 Roubaix, France \\ 3 Department of Business Administration and Textile Management, University of Borås, 50190 Borås, Sweden \\ 4 Department of Automation and Computer engineering, University of Lille, 59655 Villeneuve-d'Ascq, France \\ * Correspondence: lcwang@suda.edu.cn; Tel.: +86-188-9658-8991
}

Received: 29 November 2017; Accepted: 19 December 2017; Published: 21 December 2017

\begin{abstract}
As fashion mass customization has been developing rapidly in the recent decade, supply chain in apparel industry was required to be more flexible for meeting the need of quick response toward the dynamic changes in the fashion market. Forecast-based make-to-stock production strategy was not suitable anymore. Make-to-order strategy was employed by more and more apparel companies. However, there were still many defects in traditional make-to-order apparel supply chain, e.g., sustainability is still at a low level. In this study, we proposed a collaborative cloud service platform to develop a novel model of sustainable make-to-order apparel supply chain. A service provider selection heuristic was designed for this platform to optimally select suppliers corresponding to each received demand. Multi-agent-based simulation technology was utilized to build the proposed platform and to evaluate the new sustainable supply chain model. Experiment was conducted in the simulation to compare our new model to traditional apparel make-to-order model and model with outsourcing mechanism. Based on simulation results, the remarkable improvement in terms of sustainability of the proposed platform and corresponding supply chain model was demonstrated.
\end{abstract}

Keywords: supply chain collaboration; sustainable supply chain; make-to-order; apparel industry; agent-based simulation; optimization

\section{Introduction}

In today's fashion market, more and more customers require customization and personalization in apparel design. Mass customization has become the mainstream in apparel production, which changes apparel production, leading to small series production and high diversity in production. Moreover, with the increasing of stochastic demands from customer in apparel market, forecast-based production becomes difficult in today's apparel supply chain (SC), thus make-to-stock strategy is no longer appropriate. Therefore, make-to-order strategy, as a common strategy used to cope with these requirements, is employed by many manufacturers of apparel SC in recent years. Make-to-order strategy means that manufacturers starts production only after receiving a customer's order; production and distribution processes in the SC are all triggered by customer orders [1]. Besides the aforementioned advantages, such as meeting the desire for customization and reducing risk of forecast-based production, make-to-order strategy can also help companies avoid inventory of semi-finished products and final products which are unavoidable in make-to-stock strategy [2]. However, the make-to-order strategy also incurs many additional issues, such as long lead time [3], unsustainable relationships, high cost [4] and unbalanced capacity. There are many constraints in traditional make-to-order apparel SC model (described in Section 2.1 in detail) due to its defects. 
Customers always need to place an order to apparel manufacturer several months in advance for production. The order size should be big enough per order. Under such circumstance, late delivery still often occurs due to insufficient raw material or insufficient production capacity. Hence, traditional make-to-order SC model cannot be regarded as sustainable SC. Companies who can satisfy due dates set by customers and can shorten lead times could have a great competitive advantage. Therefore, traditional make-to-order apparel SC needs to be optimized for sustainability.

Supply chain collaboration (SCC), as an emerging concept and method in SC management in the past decades, plays a vital role in meeting the trend for sustainable SC. It has been regarded as one of the most important ways to realize sustainable SC and optimize SC performance. Many studies were conducted in SCC field. There are many methods used in SCC and they are all demonstrated in many studies as effective ways to improve SC performance, including profit sharing [5-7], information sharing [8-10], joint-decision making [11-13] and resource sharing [14-16]. In traditional make-to-order apparel SC, from fabric manufacturing echelon to apparel manufacturing echelon, each company always has a single supplier, forming independent SC structure without coordination. In today's apparel SC, many companies use outsourcing mechanism (described in detail in Section 2.2) for collaboration and optimizing resource distribution; however, it is a mechanism mainly used by big apparel companies but not by apparel SMEs (Small and medium enterprises). Therefore, it cannot be regarded as an optimized mechanism from a general supply chain scope, as it neglects apparel SMEs, which are an important part of today's apparel SC. To the best of our knowledge, there is no study regarding developing sustainable SC among apparel SMEs.

In recent years, the concept of cloud manufacturing was raised [17], although it is still under development. Cloud manufacturing "uses the network, cloud computing, service computing and manufacturing enabling technologies to transform manufacturing resources and manufacturing capabilities into manufacturing services, which can be managed and operated in an intelligent and unified way to enable the full sharing and circulating of manufacturing resources and manufacturing capabilities" [18]. Concisely, customers send orders to a cloud manufacturing central system, and the central system selects the service provider for the customer. However, cloud manufacturing is only concentrated on manufacturing sector (one echelon in SC) but not from a series of SC echelons perspective. Cloud manufacturing is a totally centralized structure; the company can hardly maintain their own decision rights [19], which is hardly accepted in the highly competitive apparel industry. Moreover, although there are several studies regarding cloud manufacturing, most only proposed the concept or model by introducing new structure or system, while no study evaluates its exact effect on SC performance based on experiment in real industry or through simulation technology. In this study, we propose a sustainable SC model by designing a collaborative cloud service platform to develop a "service to business to customer" (S2B2C) structure. Although the collaboration level among companies is enhanced, companies maintain their individual right to make decision of whether to keep an order or use the cloud service. The platform integrates multiple aforementioned SCC methods, e.g., information sharing, resource sharing, joint-decision making, etc. It aims at solving issues in existing make-to-order apparel SC models (e.g., traditional SC model and SC model with outsourcing mechanism) and increasing the sustainability of the whole SC. We utilized agent-based simulation technology to realize the platform and help us to answer several research questions in this study, including: Can our cloud platform bring more advantages to the whole SC? Is the novel model more beneficial to SMEs or to big companies? To what extent can they benefit from the novel model in terms of sustainable SC performance?

The structure of remaining paper is introduced as follows. Section 2 introduces three make-to-order apparel SC models: traditional SC model, SC model with outsourcing mechanism and our new sustainable SC model. In Section 3, the methodology used in this study is introduced. The problem is described by mathematical formulation while agent-based simulation technology is used for developing and experimenting three SC models. Experiment results and corresponding discussions are shown in Section 4. Final conclusions are presented in Section 5. 


\section{Make-To-Order Apparel Supply Chain Models}

\subsection{Traditional Make-To-Order Apparel Supply Chain Model}

In traditional make-to-order apparel SC, information flow and material flow are totally reversed, as shown in Figure 1. In a four-echelon apparel SC, customers place an order to apparel manufacturer. According to the order, apparel manufacturer starts production if there are raw materials and production capacity available. It would place an order for raw materials to dyeing manufacturer if there is insufficient raw materials. The same principle applies to dyeing manufacturer and fabric manufacturer. In the traditional model, companies always collaborate with the same downstream suppliers and upstream suppliers. They do not have connections, either with other downstream and upstream suppliers or with companies in the same SC echelon, so that every SC is decentralized and independent in a general perspective. The traditional model is still widely used in apparel SC nowadays, especially in apparel SMEs. However, make-to-order SC model still faces many difficult challenges, such as fulfilment of orders in promised lead time [1], high cost, failure to meet uncertain demand [20], high demand variation resulting in large workload fluctuations, and balance between the input rate of orders and production capacity [21].

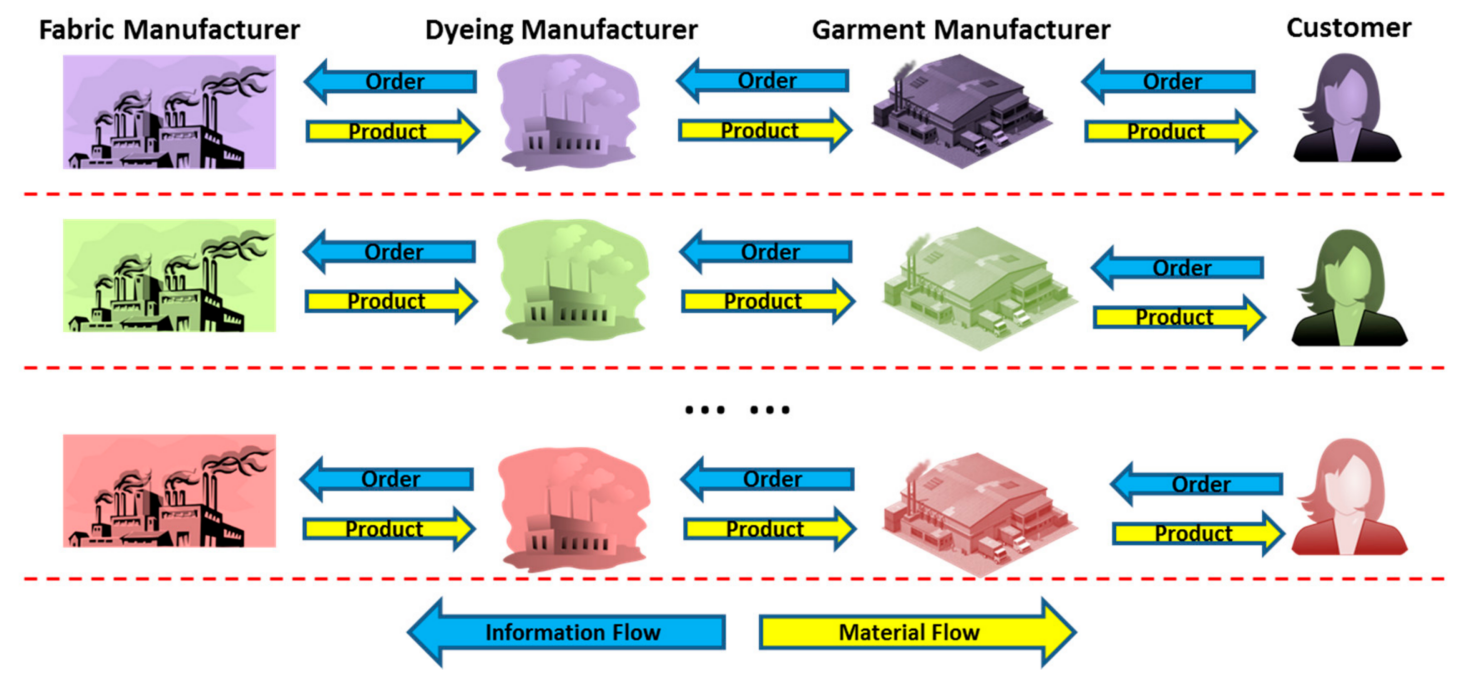

Figure 1. Traditional make-to-order apparel supply chain model.

\subsection{Make-To-Order Apparel Supply Chain Model with Outsourcing Mechanism}

Based on traditional make-to-order SC model, outsourcing mechanism is developed and is also widely utilized in apparel SC in the past decades. Outsourcing mechanism plays a vital role in today's $\mathrm{SC}$, as it could bring many advantages to companies, such as better quality of service and product delivery capability improvement [22]. In apparel SC, under most circumstances, this mechanism is usually utilized by a large company in apparel SC to re-distribute their orders to a group of SMEs. For example, 60 percent of the manufacturing jobs of ZARA were outsourced in countries close to the Zara headquarters in Spain [23], resulting in reducing the lead time to only three weeks, which helps it realize quick response to demand and to be able to reduce both markdowns and lost sales [24]. There are plenty of ways and levels to outsource certain operations in a SC. It could be realized horizontally (in the same SC echelon) or vertically (in different SC echelons) [25]. In this study, we only consider horizontally outsourcing in apparel SC. As shown in Figure 2, besides the information flow and material flow in traditional model, companies have another option to complete and distribute orders. They could partially or totally re-distribute received order to another company in the same SC echelon if they are not able to complete the order in time or do not want to produce the order. Although outsourcing mechanism is a well-established option to optimize make-to-order production, 
it is rarely applied by SMEs due to their relatively weak role in apparel industry. Consequently, it is hardly to be an optimal solution for the whole SC and SMEs in make-to-order apparel SC.

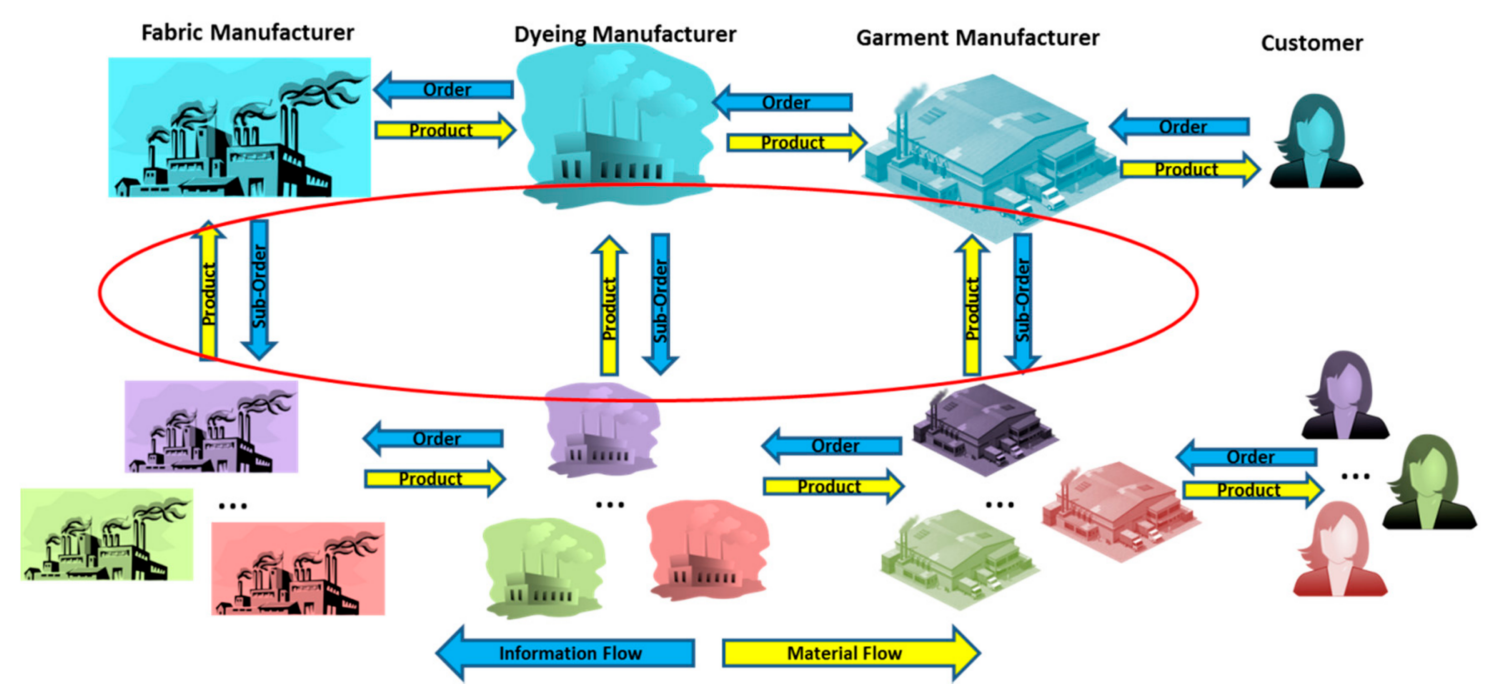

Figure 2. Make-to-order apparel supply chain model with outsourcing mechanism.

\subsection{Sustainable Make-To-Order Apparel Supply Chain Model with Collaborative Cloud Service Platform}

To optimize existing make-to-order apparel SC models, we proposed a new sustainable SC model by developing a collaborative cloud service platform (CCSP) in this study. As shown in Figure 3, CCSP is a third-party, centralizing companies in SC from all echelons. Same as the information flow and material flow in the traditional SC model, companies start production according to orders from downstream suppliers and place order to upstream suppliers for raw materials. However, if a company cannot produce a received order in time due to insufficient capacity or raw material, after evaluating the pros and cons (such as lost profit for sharing the order, penalty for late delivery and worse customer satisfaction for late delivery), it could send a demand with relevant information to CCSP. Through internal database and decision-making system, CCSP is responsible for selecting a suitable service provider in the platform to take over the order. In the new sustainable SC model, collaborative relationships are inter-organizational, inter-echelons, interactional and dynamic among companies.

\subsubsection{Information and Data System}

All companies on the CCSP should update their data to the platform database, including remaining raw material quantity, remaining production capacity and remaining orders to be processed. Those data are utilized for optimally selecting service provider in decision-making system. Moreover, companies should provide relevant information, e.g., order size, required lead time, etc., accompanying with the demand to the CCSP if they place a demand to the platform. Provided information is served as input parameters in decision-making process.

To realize information sharing and information updating in CCSP, the concept of Internet of things (IoT) and its applications could be used, such as ambient platform [26]. Internet of things is defined as "devices or sensors connected world where objects are connected, monitored, and optimised through either wired, wireless, or hybrid systems" [27]. It is regarded as one of the efficient ways to solve the problems of information sharing in the supply chain [28]. By merging applications of IoT into CCSP, all required data can be automatically shared and communicated through implemented sensors and devices. 


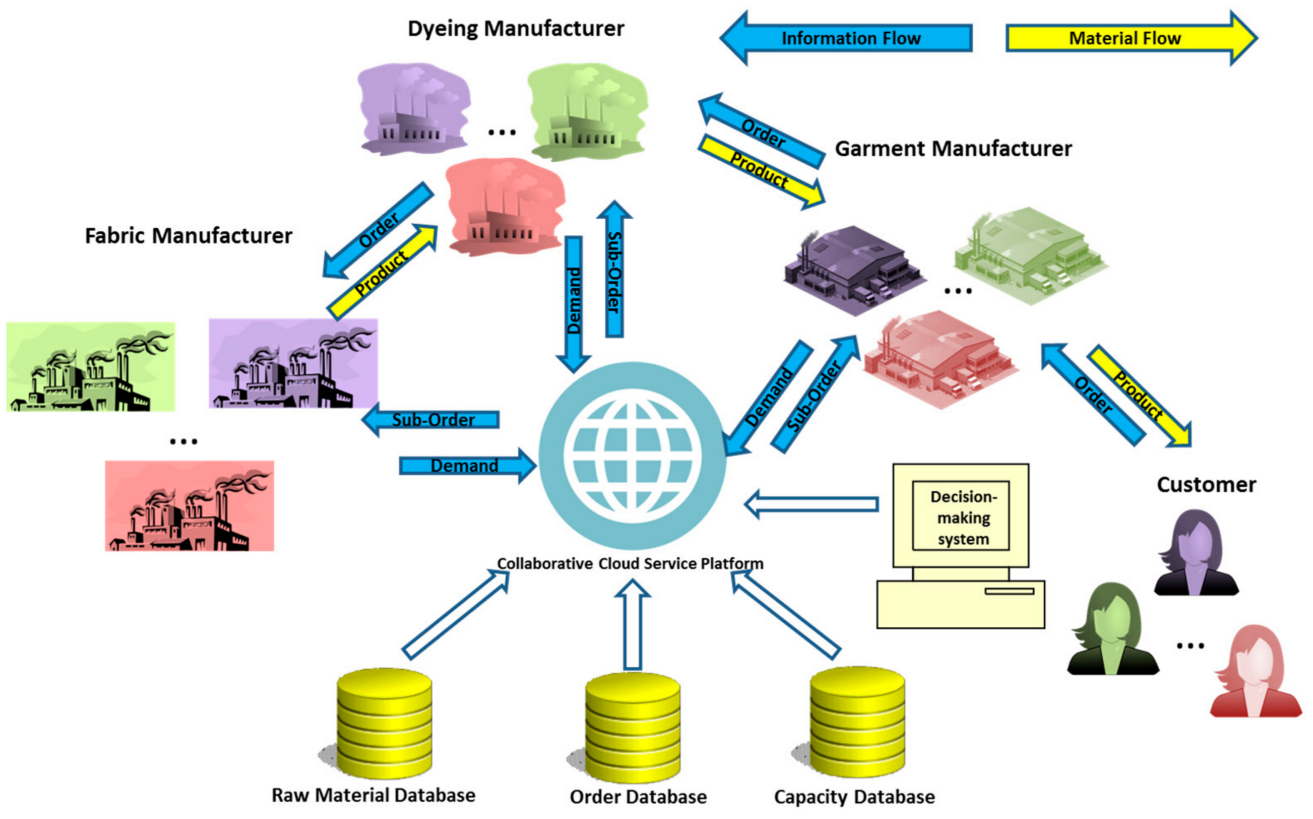

Figure 3. Sustainable make-to-order apparel supply chain model with CCSP.

In the new sustainable model, information and data are only shared to the platform but are not shared to other companies or so-called competitors. CCSP, as a third-party, does not have mutual interests with all suppliers on the platform. Therefore, there is no risk for data leakage.

\subsubsection{Decision-Making System}

Once the platform receives a demand from company, the decision-making process is activated for selecting optimal service provider to the demand, as shown in Figure 4. We designed a service provider selection heuristic (SPSH) for the decision-making system in CCSP. It could select the most suitable service provider corresponding to each received demand. In general, two screening steps and one selection step are conducted in SPSH for all potential service providers (suppliers) corresponding to the demand one by one, as follows:

1. The order queue of examined supplier is checked. If there is any order waiting in the queue for production, the supplier is not considered. If not, it would be proceeded to next step.

2. The raw material status is checked. If examined supplier has sufficient raw material for production of corresponding demand, it would be proceeded to next step. If not, the supplier is abandoned for the demand.

3. The production capacity is checked. If examined supplier has higher capacity than currently selected optimal supplier, it would be selected as new optimal supplier. If not, this supplier is abandoned for corresponding demand.

After looping through all candidate service providers with conducting the three steps, the most appropriate service provider, which has the highest production capacity with sufficient raw material and without same production task waiting in the queue, is finally selected for corresponding demand. The mathematical formulation of SPSH and its realization in simulation model are introduced in detail in the Methodology Section. 


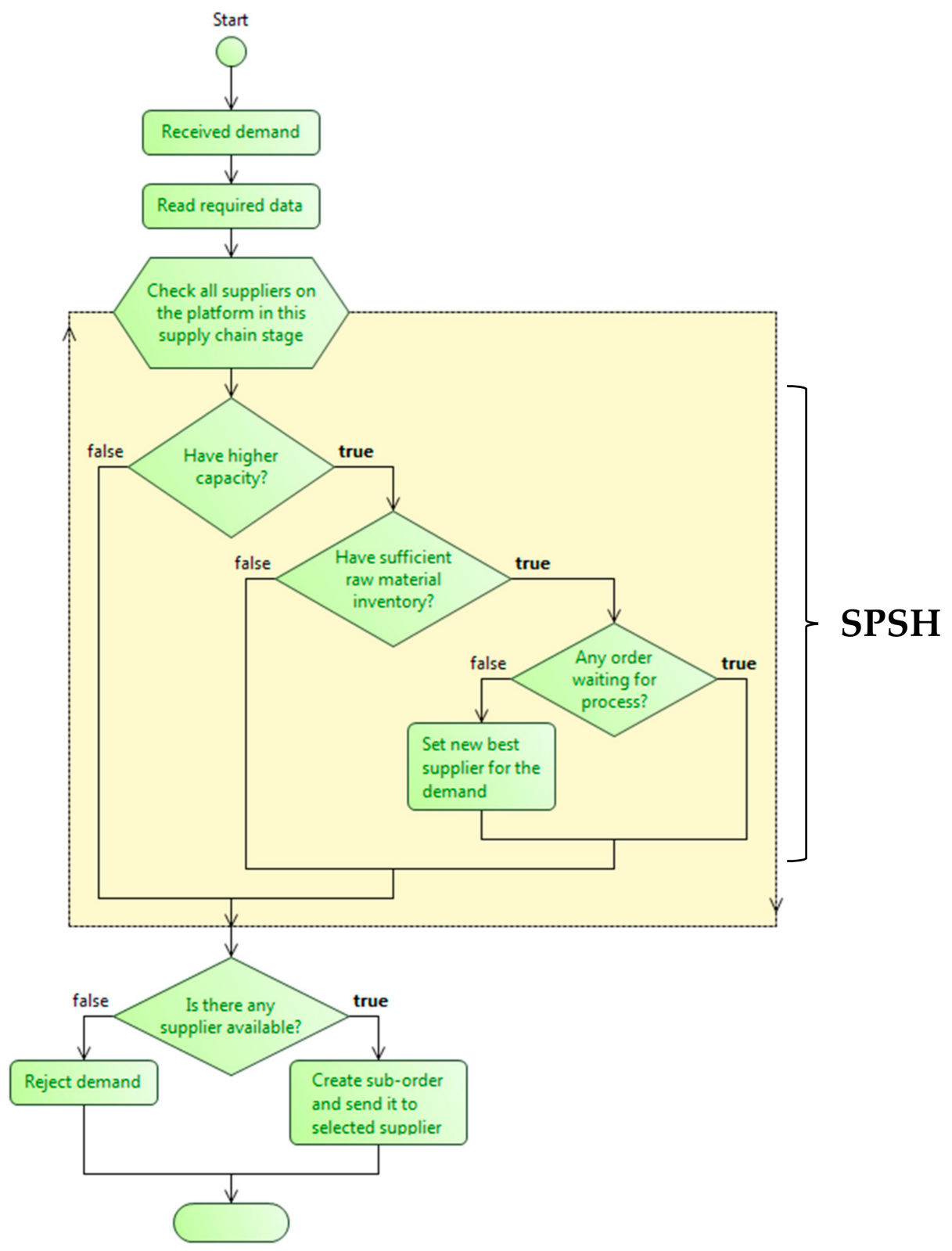

Figure 4. Flowchart of decision-making system.

\section{Methodology}

To produce a shared order from CCSP may incur additional raw material order fee and may have influence on the production of own order. Besides, manufacturers cannot gain full profits by producing a shared order from CCSP, as we defined the ratio of profit which a company can keep in terms of a shared order to stimulate their willingness to enhance collaboration and use the service of CCSP. Therefore, it is necessary to evaluate the exact influence of our proposed SC model on the whole SC and individual companies by comparing it to existing models (traditional SC model and SC model with outsourcing mechanism). In this section, we first described the problem through mathematics formulation. Considering the complexity and stochastic nature of our model, we employed agent-based simulation technology to develop three make-to-order apparel SC models introduced in Section 2. We conducted experiments in the multi-agent simulation model to explore the effect of new sustainable model and to compare it to traditional model and model with outsourcing mechanism. 


\subsection{Problem Description and Formulation}

\begin{tabular}{|c|c|}
\hline Indices: & \\
\hline$c$ & index of company in each supply chain echelon $(c=1,2,3, \ldots, C)$ \\
\hline$S$ & $\begin{array}{l}\text { index of supply chain echelon }(s=1,2,3, \ldots, S) \text { ( } 1 \text { means the most downstream supply } \\
\text { chain echelon (closest to the retailer), } S \text { means the most upstream supply chain echelon } \\
\text { (farthest from the retailer)) }\end{array}$ \\
\hline$r$ & index of retailer $(r=1,2,3, \ldots, R)$ \\
\hline$o$ & index of order $(o=1,2,3, \ldots, O)$ \\
\hline \multicolumn{2}{|l|}{ Parameters: } \\
\hline$P C_{C S}$ & production capacity of company $c$ in supply chain echelon $s$ \\
\hline$P T_{\mathcal{C S}}$ & production time of company $c$ in supply chain echelon $s$ \\
\hline$M I_{C S}$ & maximum inventory of company $c$ in supply chain echelon $s$ \\
\hline$R O P_{C S}$ & reorder point for raw material of company $c$ in supply chain echelon $s$ \\
\hline$W T_{C S}$ & working time of company $c$ in supply chain echelon $s$ \\
\hline$P D_{\mathcal{C S}}\left(=P C_{\mathcal{C S}} \times T_{\mathcal{C S}} / P T_{\mathcal{C S}}\right)$ & maximum productivity of company $c$ in supply chain echelon $s$ \\
\hline$R M_{S}$ & raw material needed per product in supply chain echelon $s$ \\
\hline$P_{S}$ & profit per product in supply chain echelon $s$ \\
\hline$O S_{o r}$ & order size for order o from retailer $r$ \\
\hline$O R_{r}$ & number of orders placed by retailer $r$ per month \\
\hline$L T_{\text {or }}$ & demanded lead time for order $o$ from retailer $r$ \\
\hline$C I$ & cost of warehouse per month \\
\hline$P L$ & penalty per day for late delivery \\
\hline$P R$ & ratio of total profit of an order when sharing the order to another company \\
\hline$B T$ & buffer time for production \\
\hline \multicolumn{2}{|l|}{ Variables: } \\
\hline$I_{C S}$ & remaining inventory of raw material of company $c$ in supply chain echelon $s$ \\
\hline$R C_{C S}$ & remaining capacity of company $c$ in supply chain echelon $s$ \\
\hline$W T_{o c s}$ & waiting time of order $o$ in the order queue of company $c$ in supply chain echelon $s$ \\
\hline $\mathrm{RO}_{c S}$ & remaining number of orders waiting in the queue of company $c$ in supply chain echelon $s$ \\
\hline$R P_{c s}$ & remaining number of products for production in company $c$ in supply chain echelon $s$ \\
\hline OS & order size for order o from company $c$ in supply chain echelon $s$ \\
\hline$L T_{\text {ocs }}$ & demanded lead time for order $o$ from company $c$ in supply chain echelon $s$ \\
\hline$P I_{o c s}$ & profit index of order o from company $c$ in supply chain echelon $s$ \\
\hline$E D_{o c s}$ & expected delayed days for order $o$ from company $c$ in supply chain echelon $s$ \\
\hline \multicolumn{2}{|l|}{ Decision variables: } \\
\hline \multicolumn{2}{|c|}{$\begin{array}{l}\text { 0, traditioanl supply chain model } \\
1 \text {, supply chain model with outsourcing mechanism } \\
2, \text { new collaborative suppy chain model with SCCSP }\end{array}$} \\
\hline
\end{tabular}

Based on the introduction of apparel SC in Section 2, we defined several variables as follows:

$$
\begin{gathered}
L T_{o c s}=\frac{O_{\text {Socs }}}{P D_{c(s+1)}}+B T \\
L T_{o c s}=L T_{o c(s-1)}-W T_{o c s}-\frac{O_{S o c s}}{P D_{c(s+1)}} \\
O S_{o c s}=M I_{c s}-I_{t c s}+R M_{t s} \times O S_{o c(s-1)} \\
E D_{o c s}=O S_{o c s} / P D_{c s}+\max \left(R P_{c s} / P D_{c s}, L T_{o c s}\right)+W T_{o c s}-L T_{o c(s-1)}
\end{gathered}
$$

Equation (1) defines demanded lead time for an order which is only used for replenish raw material inventory. Equation (2) defines demanded lead time for an order which is used for production when a company has no sufficient inventory of raw material but still can accomplish the order in time. 
Equation (3) defines demanded order size for order $o$ from company $c$ in SC echelon $s$. Equation (4) defines expected delayed days for order $o$ from company $c$ in SC echelon $s$.

Constraints and assumptions:

1. Condition for a company start production for received order:

$$
\left\{\begin{array}{l}
I_{t c s}>R M_{t s} \times O S_{o c(s-1)} \\
R C_{c s}>0
\end{array}\right.
$$

2. Condition for a company to replenish raw material:

$$
I_{t c s}-R_{M t s} \times O_{S o c(s-1)}<R O P_{c s}
$$

3. Condition for a company to share order to the platform/for a big company to outsource the order:

$$
\left\{\begin{array}{l}
R S \times E D_{o c s} \times P L>P R \times P I_{o c(s-1)} \\
E D_{o c s}>0
\end{array}\right.
$$

4. Condition for selecting company $x$ for shared order:

$$
\left\{\begin{array}{l}
I_{x s}>R M_{x s} \times O S_{o c(s-1)} \\
R C_{x s}=\max R C_{c s}>0 \\
R O_{x s}=0
\end{array}\right.
$$

\subsection{Multi-Agent Simulation Model}

In this study, multi-agent-based simulation technology was utilized to realize and compare the aforementioned model with corresponding parameters, variables, rules, assumptions and constraints. Agent-based simulation, derived from the field of artificial intelligence, can provide "an innovative and insightful way to examine SC structure and management problems" [29]; it is "a great support in methodology and technology for SC network modelling and analysis" [30]. It has been successfully used in SC research in the past decades (e.g., [31-34]). In agent-based simulation, agents play a vital role. Agents have been regarded as one of the most appropriate tools to convey information and to represent real world [33]. We defined three types of agents in our simulation model. Their definitions and internal structures are introduced in Section 3.2.1. The input parameters and evaluation criteria are, respectively, introduced in Sections 3.2.2 and 3.2.3.

\subsubsection{Agent Type}

Customer Agent Type

Customer agent type represents customers in apparel SC. It is responsible for stochastically generating apparel production orders and sending them to corresponding apparel manufacturers.

Supplier Agent Type

Fabric manufacturers, dyeing manufacturer and apparel manufacturer in apparel SC belong to supplier agent type. Each supplier agent contains process and logic for receiving order, production and placing order for raw material.

Each supplier agent has four alternative statuses when an order is received:

1. receive the order with sufficient capacity and raw material;

2. receive the order with sufficient capacity and insufficient raw material; 
3. receive the order with insufficient capacity and sufficient raw material; and

4. receive the order with insufficient capacity and insufficient raw material.

As introduced in Section 3.1, according to the condition for start production (Equation (5)) and condition for share order (Equation (7)), one out of five possible actions was chosen as follows:

1. accept the order and start production immediately;

2. accept the order and waiting for production;

3. accept the order, place an order for replenishing raw material inventory and wait for production;

4. outsource the order to a partner (only applicable for big company in the SC model with outsourcing mechanism); and

5. share the order to CCSP (only applicable in new sustainable SC model with CCSP).

The flowchart of decision-making process within supplier agent type is indicated in Figure 5.

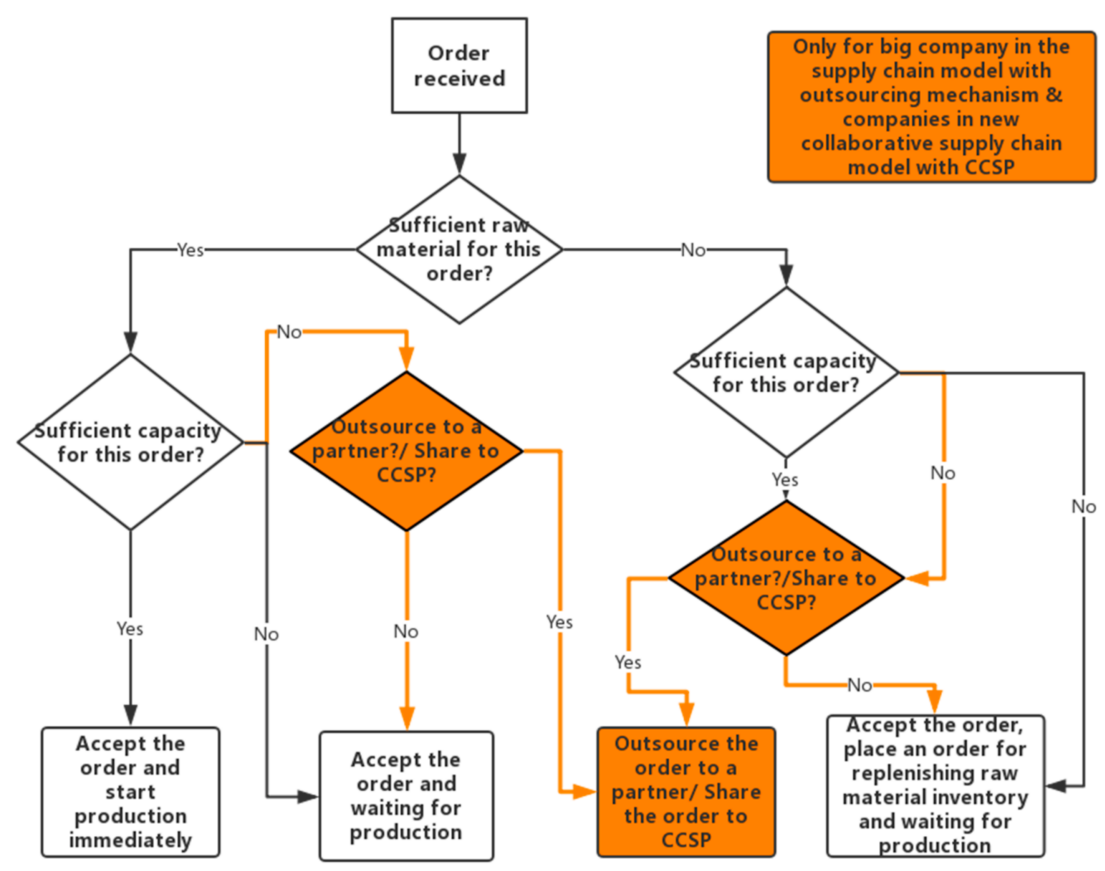

Figure 5. Flowchart of decision-making process within supplier agent type.

\section{Collaborative Cloud Service Platform Agent}

In our simulation model, CCSP is a unique agent type. Supplier agent sends demand to this agent if supplier decides to share the order. Once a demand is received in this agent type, the SPSH as introduced in Section 2.3.2 is activated. Based on Figure 4, the general java code of SPSH in the agent-based simulation model is illustrated as follows:

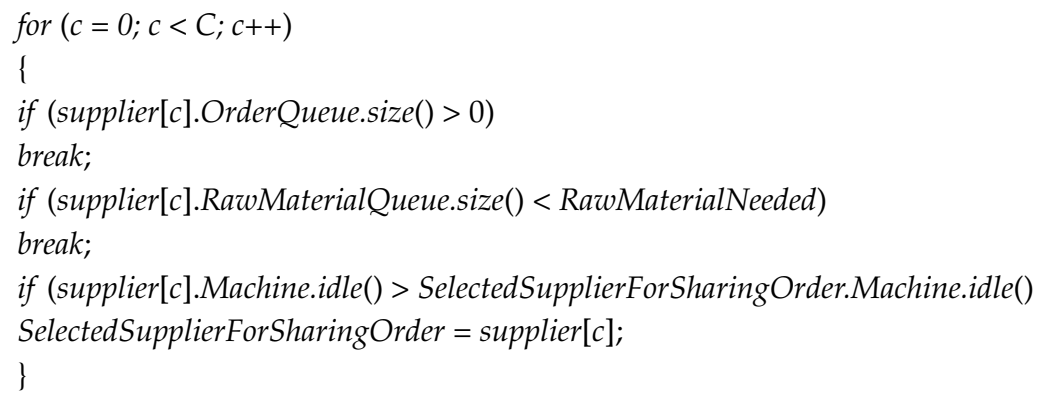




\subsubsection{Input Parameters in the Simulation}

We collected data from a big apparel company located in Jiangsu Province, China. This company applied make-to-order strategy for production and had many SME partners to implement outsourcing mechanism. We also conducted several interviews with professionals working in apparel industry. In our simulation model, there are 50 companies (1 big company and 49 SMEs) in each SC echelon. The differences between big company and SMEs are reflected in their capacity scale, warehouse scale and order arrival rate per month. We only considered one type of production, namely the production of shirt, to reduce the complexity of simulation model. We also assumed that the raw material inventory of all fabric manufacturers is infinity, as they are on the most upstream echelon in our SC model. The PR are different between outsourcing mechanism and sharing to CCSP, as big manufacturer has leading power in the SC model with outsourcing mechanism while CCSP provides an equal position for all players on the platform. Discrete uniform distribution was employed on some input parameters to make sure every company is unique. Probability distribution was also used for order size and demanded lead time, so that every order placed by customer is stochastic and different from each other. Based on collected data, interviews and aforementioned discussions, we obtained input parameters for the simulation model, as shown in Table 1.

\subsubsection{Evaluation Criteria}

To evaluate and compare the sustainability of three SC models, we defined five sustainable SC key performance indicators (KPIs) as criteria:

- Unit cost $=($ Total inventory cost + Total late delivery penalty + Total raw Material Cost $) /$ Yield of a company

- Average lead time: The average duration in a company from receiving an order to completing the order

- $\quad$ Facility utilization = Effective machine operating time/Total working time of a company

- $\quad$ Delayed order percentage $=$ Total number of not-on-time completed order/Total number of completed order of a company

- Yield: The total number of products produced in a company in the given period of time

The five KPIs served as output of the simulation. They covered various perspectives of sustainability in SC, e.g., financial perspective, customer satisfaction perspective, efficiency perspective and operation perspective. Therefore, the model could be evaluated comprehensively in terms of sustainability according to the five KPIs. 
Table 1. Input parameters.

\begin{tabular}{|c|c|c|c|c|c|c|}
\hline & $\begin{array}{l}\text { Big Apparel } \\
\text { Manufacturer }\end{array}$ & $\begin{array}{c}\text { Apparel } \\
\text { Manufacturing SMEs }\end{array}$ & $\begin{array}{l}\text { Big Dyeing } \\
\text { Manufacturer }\end{array}$ & Dyeing SMEs & $\begin{array}{l}\text { Big Fabric } \\
\text { Manufacturer }\end{array}$ & $\begin{array}{c}\text { Fabric } \\
\text { Manufacturing SMEs }\end{array}$ \\
\hline$P C_{c S}$ & 120 sewing machines & $\begin{array}{l}\text { Uniform }(30,40) \\
\text { sewing machines }\end{array}$ & 8 dyeing machines & $\begin{array}{c}\text { Uniform }(2,3) \\
\text { dyeing machines }\end{array}$ & 12 weaving machines & $\begin{array}{c}\text { Uniform }(5,8) \\
\text { weaving machines }\end{array}$ \\
\hline$P T_{\mathcal{C S}}$ & $35 \mathrm{~min}$ & $35 \mathrm{~min}$ & $420 \mathrm{~min}$ & $420 \mathrm{~min}$ & $2.08 \mathrm{~min}$ & $2.08 \mathrm{~min}$ \\
\hline$M I_{C S}$ & $8000 \mathrm{~m}$ & Uniform $(2000,4000) \mathrm{m}$ & $16,000 \mathrm{~m}$ & Uniform $(4000,8000) \mathrm{m}$ & Infinity & Infinity \\
\hline$R O P_{\mathcal{C S}}$ & $4000 \mathrm{~m}$ & Uniform $(1000,2000) \mathrm{m}$ & $8000 \mathrm{~m}$ & Uniform $(2000,4000) \mathrm{m}$ & - & - \\
\hline$W T_{\mathcal{~ S S}}$ & 8 h/day & $8 \mathrm{~h} /$ day & 8 h/day & 8 h/day & $8 \mathrm{~h} /$ day & $8 \mathrm{~h} /$ day \\
\hline$R M_{S}$ & Uniform $(1.5,2) \mathrm{m} /$ piece & Uniform $(1.5,2) \mathrm{m} /$ piece & $1 \mathrm{~m} / \mathrm{m}$ & $1 \mathrm{~m} / \mathrm{m}$ & - & - \\
\hline$P_{s}$ & $\begin{array}{l}\text { Uniform }(5,15) \\
\text { CNY/piece }\end{array}$ & $\begin{array}{l}\text { Uniform }(5,15) \\
\text { CNY/piece }\end{array}$ & $\begin{array}{l}\text { Uniform }(0.5,1.5) \\
\mathrm{CNY} / \mathrm{m}\end{array}$ & $\begin{array}{l}\text { Uniform }(0.5,1.5) \\
\mathrm{CNY} / \mathrm{m}\end{array}$ & $\begin{array}{l}\text { Uniform }(0.5,1.5) \\
\mathrm{CNY} / \mathrm{m}\end{array}$ & $\begin{array}{l}\text { Uniform }(0.5,1.5) \\
\mathrm{CNY} / \mathrm{m}\end{array}$ \\
\hline$O S_{o r}$ & $\begin{array}{l}\text { Uniform }(30,1000) \\
\text { pieces/order }\end{array}$ & $\begin{array}{l}\text { Uniform }(30,1000) \\
\text { pieces/order }\end{array}$ & - & - & - & - \\
\hline$O R_{r}$ & 60 orders /month & $\begin{array}{l}\text { Uniform }(15,20) \\
\text { orders/month }\end{array}$ & - & - & - & - \\
\hline$L T_{\text {or }}$ & Triangular $(5,20,30)$ & Triangular $(5,20,30)$ & - & - & - & - \\
\hline$C I$ & 40,000 CNY/month & $\begin{array}{c}\text { Uniform }(10,000,20,000) \\
\text { CNY/month }\end{array}$ & 40,000 CNY/month & $\begin{array}{l}\text { Uniform }(10,000,20,000) \\
\text { CNY/month }\end{array}$ & 40,000 CNY/month & $\begin{array}{c}\text { Uniform }(10,000,20,000) \\
\text { CNY } / \text { month }\end{array}$ \\
\hline$P L$ & $500 \mathrm{CNY} /$ day & $500 \mathrm{CNY} /$ day & $500 \mathrm{CNY} /$ day & $500 \mathrm{CNY} /$ day & $500 \mathrm{CNY} /$ day & $500 \mathrm{CNY} /$ day \\
\hline$P R$ & $\begin{array}{c}50 \% \text { (outsourcing) } / \\
70 \% \text { (CCSP) }\end{array}$ & $\begin{array}{c}50 \% \text { (outsourcing) / } \\
70 \% \text { (CCSP) }\end{array}$ & $\begin{array}{c}50 \% \text { (outsourcing) } / \\
70 \% \text { (CCSP) }\end{array}$ & $\begin{array}{c}50 \% \text { (outsourcing) } / \\
70 \% \text { (CCSP) }\end{array}$ & $\begin{array}{c}50 \% \text { (outsourcing) } / \\
70 \% \text { (CCSP) }\end{array}$ & $\begin{array}{c}50 \% \text { (outsourcing)/ } \\
70 \% \text { (CCSP) }\end{array}$ \\
\hline$B T$ & Uniform $(5,10)$ days & Uniform $(5,10)$ days & Uniform $(5,10)$ days & Uniform $(5,10)$ days & Uniform $(5,10)$ days & Uniform $(5,10)$ days \\
\hline
\end{tabular}




\section{Results and Discussion}

We run three SC models for 30 replications, respectively, in simulation for a duration of 180 days. For each replication, the seed of random number generator was same for three models to guarantee the validation of comparison. We processed output data and calculated five predefined KPIs of each company in each replication. Then, we calculated the average value of KPIs for big company, SMEs and whole cluster (all companies) in each SC echelon in each replication. As we assumed the inventory is infinite for fabric manufacturing echelon, we did not take companies in this SC echelon into consideration for further analysis. Finally, we obtained the range of each KPIs and also calculated the $95 \%$ confidence interval (CI) for mean of 30 replications. All corresponding statistics are shown in Appendix A. The output data obtained by simulation of SC model with outsourcing mechanism are close to the real data we collected from the company in Jiangsu, China. Besides, we built our simulation model step by step, as introduced in Section 3.2, and undertook strict debugging process. Therefore, our simulation model could be regarded as representative and validated to our case.

The comparisons of mean value of each KPIs of different clusters and companies are shown in Figures 6-9. Based on Figures 6 and 7, we can see that new proposed SC model performed much better for the whole apparel industry cluster in all aspects compared to traditional SC model and SC model with outsourcing mechanism. For apparel manufacturer cluster, the improvement was remarkable in the new model in terms of average lead time, unit cost and delayed order percentage: at least $29.62 \%$ improvement was obtained. For dyeing manufacturer cluster, the improvement was also significant in new model in terms of unit cost and delayed order percentage, with at least $26.63 \%$ improvement compared to the two other models. Therefore, our proposed SC model with CCSP is optimal choice for apparel industry cluster in each SC echelon. If we compare the SC model with outsource mechanism to traditional SC model, the difference is not significant at all: slight improvements were obtained in some aspects, while declines were also discovered in other aspects. Therefore, outsourcing mechanism cannot bring general benefits to the whole apparel industry cluster.
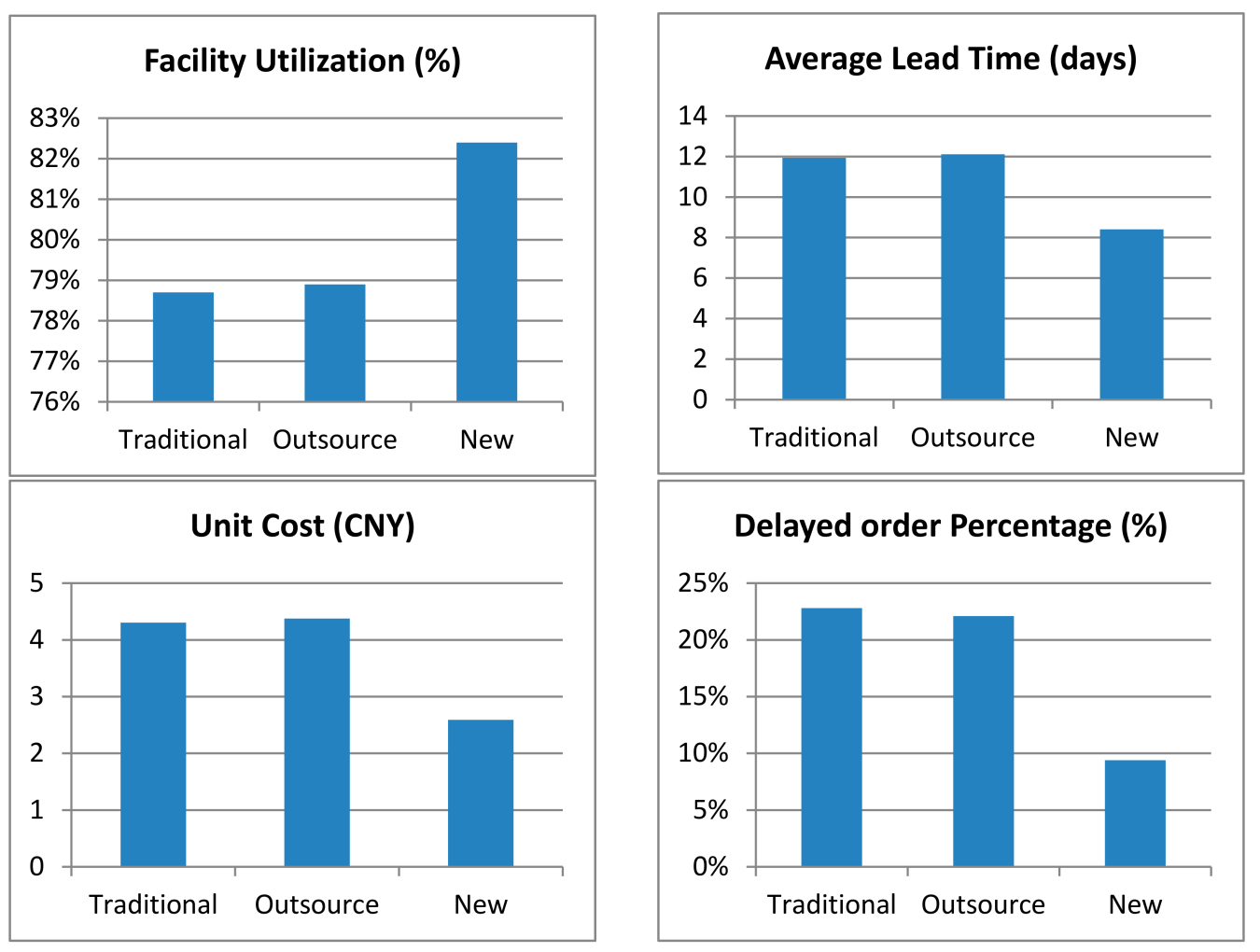

Figure 6. Cont. 


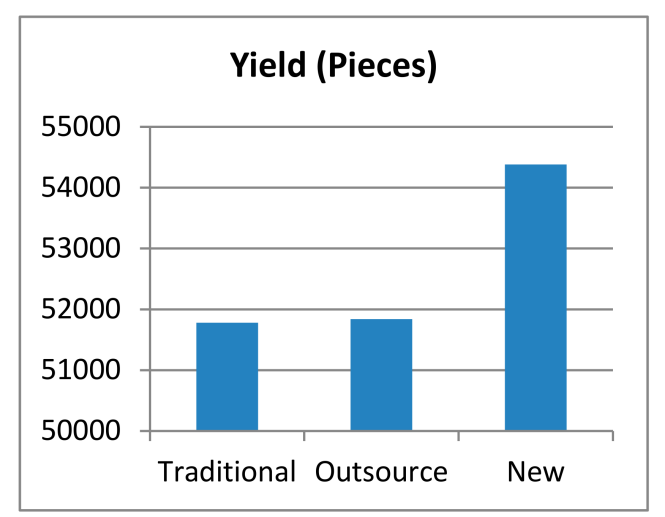

Figure 6. KPIs of apparel manufacturer cluster.

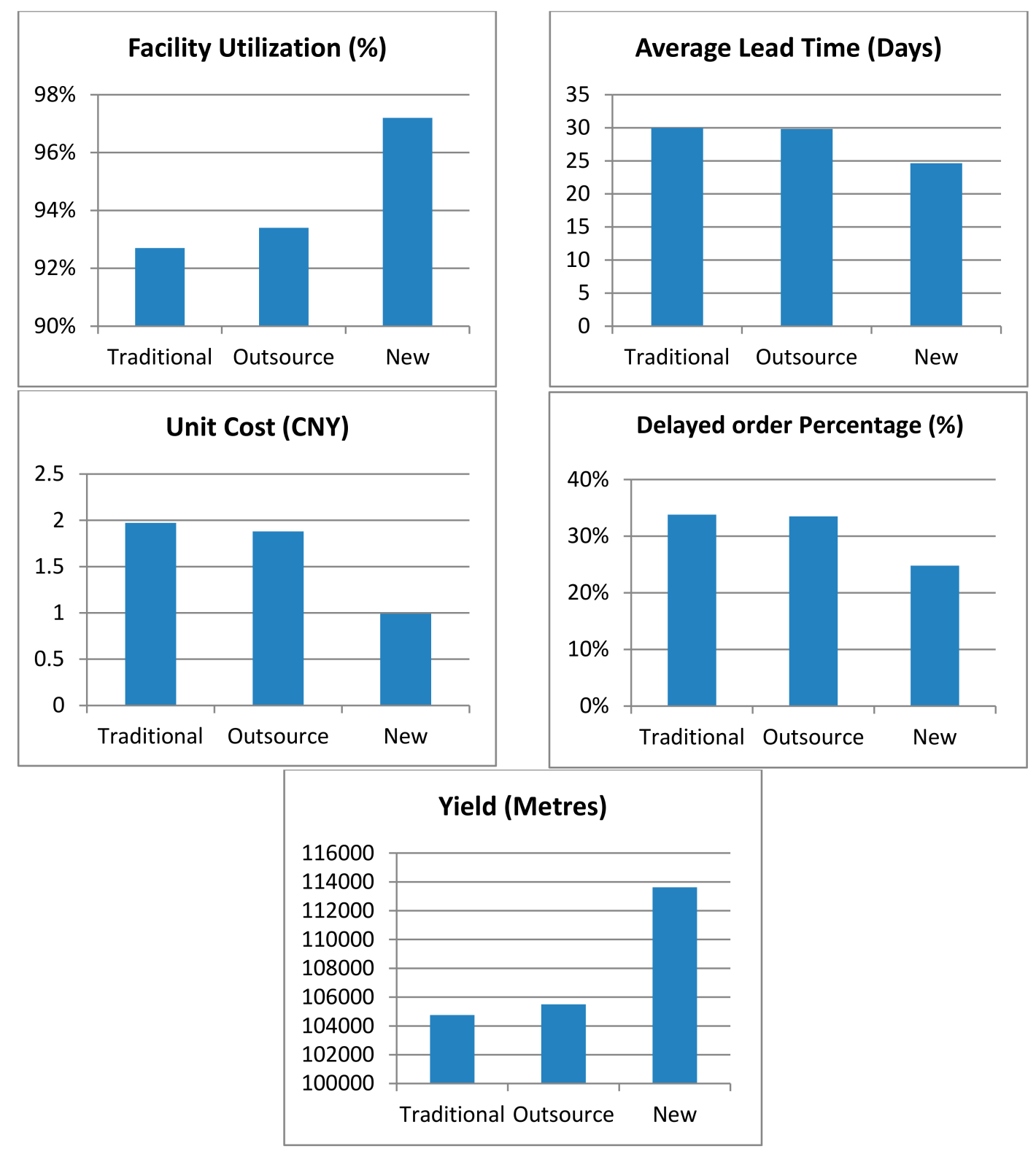

Figure 7. KPIs of dyeing manufacturer cluster. 


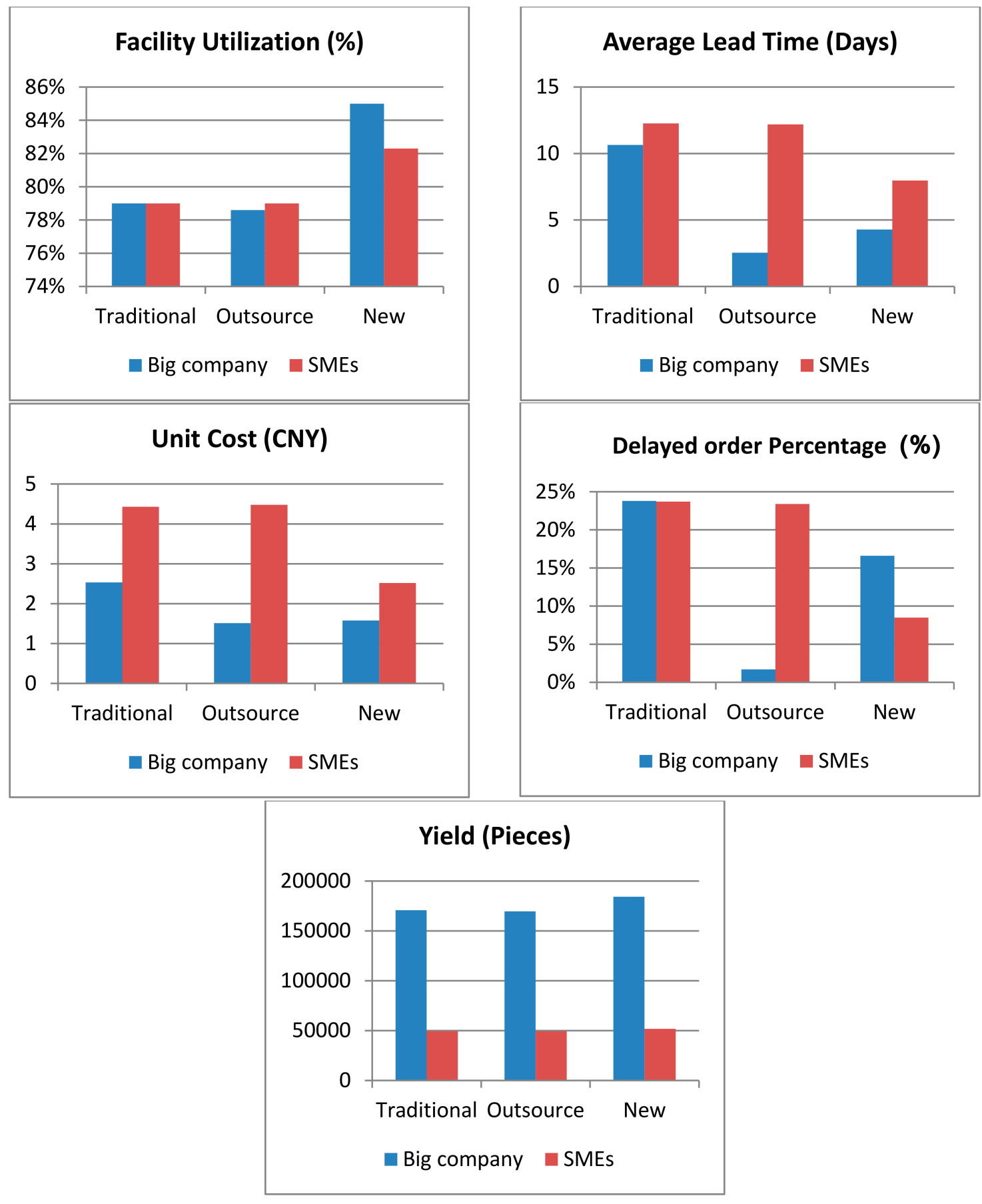

Figure 8. KPIs of big apparel manufacturer and apparel manufacturing SMEs.

According to Figure 8, we can see the influence of outsourcing mechanism and CCSP on apparel manufacturers of different scales. For big apparel manufacturers, outsourcing mechanism significantly increased their SC performance in all checked aspects, especially in terms of average lead time, unit cost and delayed order percentage, with a dramatic raise of $40.21-92.86 \%$ compared to traditional SC model. Outsourcing mechanism performed much better than new SC model with CCSP in these three aspects. However, its improvements were not as high as new SC model in terms of facility utilization and yield. This is because big manufacturers outsource many orders to their SME partners, thus they are not always in full workload. Therefore, outsourcing mechanism is a better choice for big apparel manufacturers. For apparel manufacturing SMEs, the effect is different. The performance of SC 
model with outsourcing mechanism and traditional SC model were almost the same in five checked aspects. We expected that SMEs could get increase in facility utilization and yield, as they may receive additional orders from big apparel manufacturers. However, it is not reflected in the simulation model. On the other hand, new sustainable model helps apparel manufacturing SMEs achieve dramatic upgrade in all five KPIs. Therefore, CCSP can bring comprehensive benefits to apparel SMEs.

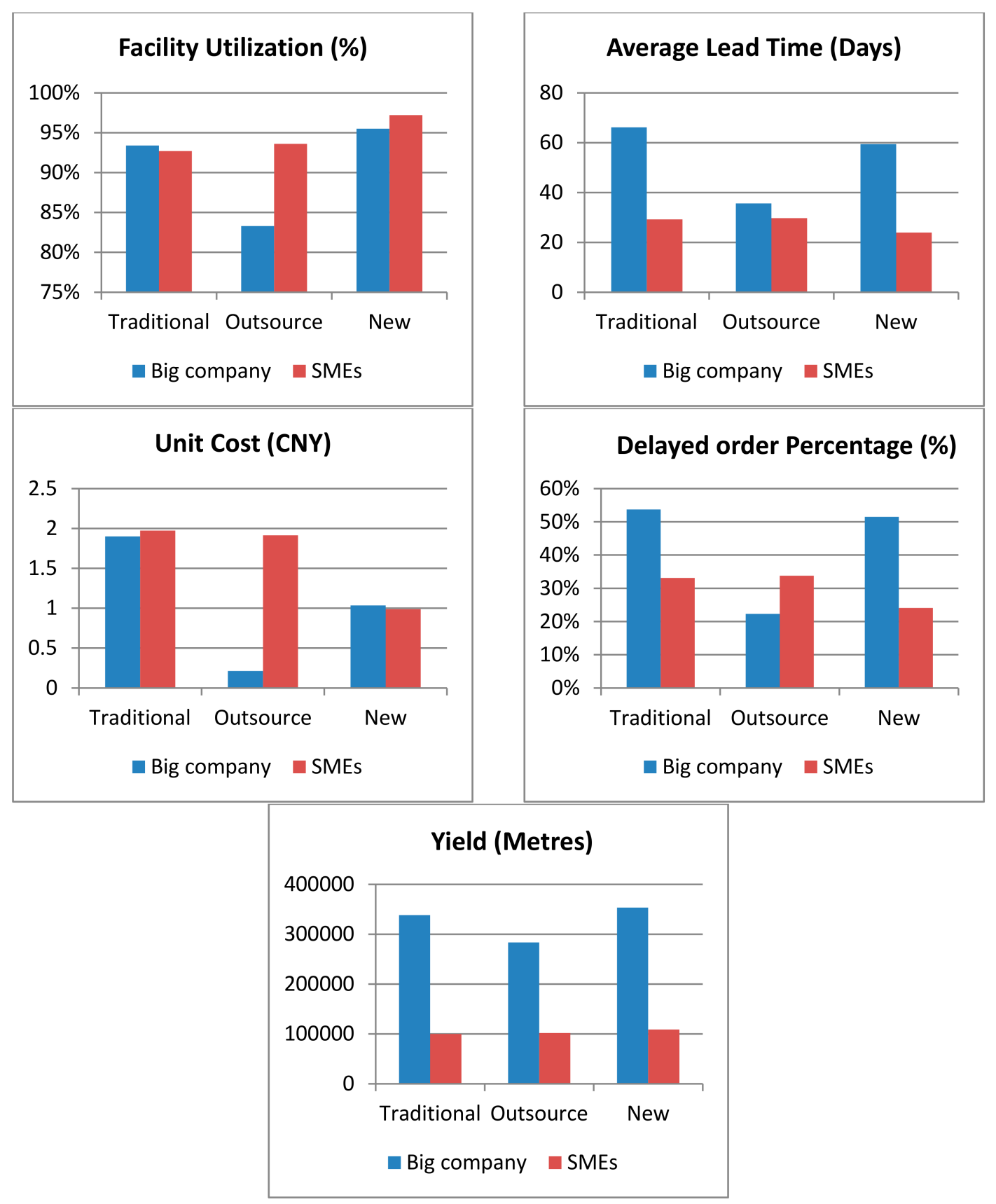

Figure 9. KPIs of big dyeing manufacturer and dyeing SMEs.

According to Figure 9, we can see the influence of outsourcing mechanism and CCSP on dyeing manufacturers of different scales. We can find similar pattern as the comparison for big apparel manufacturer. Remarkable improvements were obtained with outsourcing mechanism in terms of average lead time (a $46.11 \%$ decrease), unit cost (an $88.8 \%$ decrease) and delayed order percentage (a $58.47 \%$ decrease). However, there is also a $10.81 \%$ decrease in facility utilization and $16.20 \%$ 
decrease in yield of big dyeing manufacturer compared to traditional SC model, which are unexpected. Even though there is no dramatic difference between new sustainable model and traditional model, every checked KPI was improved to some extent in new sustainable model. For dyeing SMEs, we can get same conclusion as outcome for apparel manufacturing SMEs. SC performances of dyeing SMEs are almost the same in outsourcing mechanism and traditional model. Improvements in all aspects (from $4.85 \%$ to $49.87 \%$ ) were achieved in new sustainable model for dyeing SMEs. Therefore, CCSP is the optimal scenario for dyeing SMEs in apparel SC.

\section{Conclusions}

In this study, we proposed a collaborative cloud service platform to create a sustainable make-to-order apparel supply chain model. A service provider selection heuristic was designed for the platform to select optimal supplier corresponding to each demand received by the platform. We utilized multi-agent-based simulation technology to build our proposed platform and to evaluate new sustainable SC model. We also conducted simulation experiment to compare our new model to traditional apparel make-to-order SC model and SC model with outsourcing mechanism. Based on simulation experiment results, we demonstrated the remarkable advantage of our proposed sustainable SC model with CCSP. We also obtained several conclusions:

1. In general, CCSP can bring comprehensive benefits to companies in every echelon of apparel SC, namely dyeing manufacturing echelon and apparel manufacturing echelon. CCSP integrates information sharing, resource sharing, joint decision-making and profit sharing into one novel sustainable SC model, which is an innovative approach to enhance supply chain sustainability and overcome defects in current make-to-order apparel SC.

2. The SPSH heuristics can provide optimal solution in decision-making for service provider selection. Therefore, optimal resource allocation was achieved in apparel SC, leading to significant improvements in multiple aspects of sustainable SC performance.

3. Outsourcing, as a widely used mechanism in apparel industry currently, is not an optimized choice in terms of SC sustainability for the whole cluster in apparel industry. There is no significant difference in terms of SC performance of whole cluster between make-to-order apparel SC model with outsourcing mechanism and traditional make-to-order apparel SC model.

4. Outsourcing mechanism is still an outstanding scenario for big company in apparel industry. Although our proposed new model can, to some extent, improve SC sustainable performance of big companies, outsourcing mechanism can bring much higher improvements in some aspects, e.g., average lead time, unit cost and delayed order percentage.

5. Our new sustainable model with CCSP helps apparel SMEs obtain dramatically enhanced performance in make-to-order apparel supply chain. It provides a service platform for small businesses in apparel industry to collaborate and share with each other for increasing both overall and individual competitive power. It is the optimal and desirable choice for apparel companies, especially apparel SMEs, to survive and become competitive in the future trend of sustainable SC.

In previous research, studies regarding cloud manufacturing mainly proposed the concept or model by introducing new structure or system, while no study evaluated its exact effect on SC performance. We obtained exact effect of CCSP on SC performance through multi-agent simulation to fill this gap. Moreover, we developed a sustainable make-to-order SC model by mainly considering the sustainable performance of apparel SMEs, which play an important part in today's apparel industry. This was never done in previous practice or research. The outcome of this study could be applied in the whole apparel SC. Apparel companies, especially SMEs, could benefit from the cloud platform with corresponding sustainable SC model proposed in this study. Although this study is aiming at apparel industry, the conceptual model with collaborative cloud service platform can also be instructive to other industries: companies can implement CCSP to improve sustainability performance. The concept, structure and heuristic of CCSP can be a promising direction in future SC research; it can be also 
useful in several other popular aspects, such as Internet of Things, industry 4.0 and intelligent system. Such innovative model could also be a starting point for the ideal C2B model in future SC. However, there are also some limitations in this study. For example, we did not consider the influence of CCSP on logistics activities or its performance under different workload (busy season and idle season). It could also be very interesting to study the effect of CCSP on different aspects under distinct conditions in future research. Besides, CCSP only provides a platform for companies to share their redundant resource and orders which they cannot complete. It could be interesting to integrate more intelligent functions into the platform, e.g., sharing inventory or collaborative raw material purchase. They are all expected to be studied in future research.

Acknowledgments: This work is supported by the joint doctorate programme "Sustainable Management and Design for Textiles", which is funded by the European Commission's Erasmus Mundus programme. This work is also supported by the National Natural Science Foundation of China (Grant No. 61702352).

Author Contributions: K.M. proposed the initial idea; carried out the modelling, computational part and experiments; and wrote most of the manuscript. L.W. contributed to the ideas of model and data collection. L.W. revised the manuscript. Y.C. revised the manuscript.

Conflicts of Interest: The authors declare no conflict of interest. The founding sponsors had no role in the design of the study; in the collection, analyses, or interpretation of data; in the writing of the manuscript, and in the decision to publish the results. 


\section{Appendix A}

Table A1. KPI statistics of apparel manufacturer cluster.

\begin{tabular}{|c|c|c|c|c|c|c|}
\hline Model & Statistics Item & $\begin{array}{c}\text { Average Facility } \\
\text { Utilization }\end{array}$ & $\begin{array}{c}\text { Average Lead } \\
\text { Time (Days) }\end{array}$ & $\begin{array}{l}\text { Average Unit } \\
\text { Cost (CNY) }\end{array}$ & $\begin{array}{l}\text { Delayed Order } \\
\text { Percentage }\end{array}$ & Total Yield (Pieces) \\
\hline Traditional & $\begin{array}{l}95 \% \text { CI for mean } \\
\text { Range }\end{array}$ & $\begin{array}{l}0.790 \pm 0.005 \\
(0.763,0.818)\end{array}$ & $\begin{array}{c}12.234 \pm 0.466 \\
(10.281,14.492)\end{array}$ & $\begin{array}{l}4.393 \pm 0.199 \\
(3.347,5.344)\end{array}$ & $\begin{array}{c}0.232 \pm 0.014 \\
(0.163,0.296)\end{array}$ & $\begin{array}{c}2,588,719.9 \pm 13,388.206 \\
(2,525,445,2,681,497)\end{array}$ \\
\hline Outsource & $\begin{array}{l}\text { 95\% CI for mean } \\
\text { Range }\end{array}$ & $\begin{array}{l}0.791 \pm 0.005 \\
(0.767,0.815)\end{array}$ & $\begin{array}{c}11.994 \pm 0.363 \\
(10.189,14.189)\end{array}$ & $\begin{array}{l}4.419 \pm 0.159 \\
(3.452,5.152)\end{array}$ & $\begin{array}{l}0.219 \pm 0.011 \\
(0.166,0.278)\end{array}$ & $\begin{array}{c}2,586,674.5 \pm 12,560.559 \\
(2,510,058,2,652,278)\end{array}$ \\
\hline New & $\begin{array}{l}95 \% \text { CI for mean } \\
\text { Range }\end{array}$ & $\begin{array}{l}0.823 \pm 0.005 \\
(0.802,0.858)\end{array}$ & $\begin{array}{l}7.897 \pm 0.479 \\
(6.072,10.605)\end{array}$ & $\begin{array}{l}2.501 \pm 0.074 \\
(2.253,2.953)\end{array}$ & $\begin{array}{l}0.081 \pm 0.013 \\
(0.035,0.156)\end{array}$ & $\begin{array}{c}2,722,699.233 \pm 13,351.842 \\
\quad(2,663,983,2,781,564)\end{array}$ \\
\hline
\end{tabular}

Table A2. KPI statistics of big apparel manufacturer.

\begin{tabular}{|c|c|c|c|c|c|c|}
\hline Model & Statistics Item & $\begin{array}{l}\text { Average Facility } \\
\text { Utilization }\end{array}$ & $\begin{array}{l}\text { Average Lead } \\
\text { Time (Days) }\end{array}$ & $\begin{array}{l}\text { Average Unit } \\
\text { Cost (CNY) }\end{array}$ & $\begin{array}{l}\text { Delayed Order } \\
\text { Percentage }\end{array}$ & Total Yield (Pieces) \\
\hline Traditional & $\begin{array}{l}95 \% \text { CI for mean } \\
\text { Range }\end{array}$ & $\begin{array}{c}0.79 \pm 0.004 \\
(0.755,0.804)\end{array}$ & $\begin{array}{l}10.642 \pm 1.561 \\
(2.357,18.345)\end{array}$ & $\begin{array}{c}2.532 \pm 0.43 \\
(1.53,6.487)\end{array}$ & $\begin{array}{c}0.338 \pm 0.048 \\
(0,0.504)\end{array}$ & $\begin{array}{c}17,0748.9 \pm 906.168 \\
(163,014,173,626)\end{array}$ \\
\hline Outsource & $\begin{array}{l}95 \% \text { CI for mean } \\
\text { Range }\end{array}$ & $\begin{array}{l}0.786 \pm 0.018 \\
(0.722,0.896)\end{array}$ & $\begin{array}{l}2.542 \pm 0.725 \\
(1.508,12.176)\end{array}$ & $\begin{array}{l}1.514 \pm 0.035 \\
(1.315,1.767)\end{array}$ & $\begin{array}{l}0.017 \pm 0.032 \\
\quad(0,0.473)\end{array}$ & $\begin{array}{c}169,582.033 \pm 3915.593 \\
(155,471,193,987)\end{array}$ \\
\hline New & $\begin{array}{l}95 \% \text { CI for mean } \\
\text { Range }\end{array}$ & $\begin{array}{l}0.85 \pm 0.008 \\
(0.81,0.899)\end{array}$ & $\begin{array}{l}4.286 \pm 0.59 \\
(2.634,8.523)\end{array}$ & $\begin{array}{c}1.579 \pm 0.063 \\
(1.37,2.059)\end{array}$ & $\begin{array}{c}0.166 \pm 0.058 \\
(0,0.641)\end{array}$ & $\begin{array}{c}184,213.8 \pm 1875.816 \\
(175,189,195,061)\end{array}$ \\
\hline
\end{tabular}

Table A3. KPI statistics of apparel manufacturing SMEs.

\begin{tabular}{ccccccc}
\hline \multirow{2}{*}{ Model } & Statistics Item & $\begin{array}{c}\text { Average Facility } \\
\text { Utilization }\end{array}$ & $\begin{array}{c}\text { Average Lead } \\
\text { Time (Days) }\end{array}$ & $\begin{array}{c}\text { Average Unit } \\
\text { Cost (CNY) }\end{array}$ & $\begin{array}{c}\text { Delayed Order } \\
\text { Percentage }\end{array}$ & $\begin{array}{c}\text { Total Yield (Pieces) } \\
\text { Traditional }\end{array}$ \\
& $95 \%$ CI for mean & $0.79 \pm 0.005$ & $12.266 \pm 0.467$ & $4.431 \pm 0.202$ & $0.237 \pm 0.014$ & $2,417,971 \pm 13,460.328$ \\
& Range & $(0.762,0.818)$ & $(10.34,14.556)$ & $(3.379,5.413)$ & $(0.167,0.307)$ & $(2,354,267,2,510,791)$ \\
\hline \multirow{2}{*}{ Outsource } & $95 \%$ CI for mean & $0.79 \pm 0.005$ & $12.187 \pm 0.368$ & $4.478 \pm 0.163$ & $0.234 \pm 0.012$ & $2,417,092.467 \pm 11,904.965$ \\
& Range & $(0.768,0.816)$ & $(10.365,14.377)$ & $(3.491,5.228)$ & $(0.177,0.298)$ & $(2,347,572,2,492,500)$ \\
\hline \multirow{2}{*}{ New } & $95 \%$ CI for mean & $0.823 \pm 0.005$ & $7.971 \pm 0.48$ & $2.52 \pm 0.074$ & $0.085 \pm 0.013$ & $2,538,485.433 \pm 12,926.34$ \\
& Range & $(0.801,0.858)$ & $(6.135,10.676)$ & $(2.268,2.972)$ & $(0.037,0.163)$ & $(2,487,476,2,596,009)$ \\
\hline
\end{tabular}


Table A4. KPI statistics of dyeing manufacturer cluster.

\begin{tabular}{|c|c|c|c|c|c|c|}
\hline Model & Statistics Item & $\begin{array}{l}\text { Average Facility } \\
\text { Utilization }\end{array}$ & $\begin{array}{l}\text { Average Lead } \\
\text { Time (Days) }\end{array}$ & $\begin{array}{l}\text { Average Unit } \\
\text { Cost (CNY) }\end{array}$ & $\begin{array}{l}\text { Delayed Order } \\
\text { Percentage }\end{array}$ & Total Yield (m) \\
\hline Traditional & $\begin{array}{l}95 \% \text { CI for mean } \\
\text { Range }\end{array}$ & $\begin{array}{l}0.927 \pm 0.003 \\
(0.912,0.912)\end{array}$ & $\begin{array}{c}29.991 \pm 0.7 \\
(25.556,35.409)\end{array}$ & $\begin{array}{l}1.972 \pm 0.08 \\
(1.536,2.667)\end{array}$ & $\begin{array}{l}0.238 \pm 0.012 \\
(0.266,0.439)\end{array}$ & $\begin{array}{c}5,237,867.567 \pm 25,954.387 \\
\quad(5,154,296,5,422,632)\end{array}$ \\
\hline Outsource & $\begin{array}{l}95 \% \text { CI for mean } \\
\text { Range }\end{array}$ & $\begin{array}{l}0.934 \pm 0.004 \\
(0.901,0.954)\end{array}$ & $\begin{array}{l}29.824 \pm 0.836 \\
(25.404,34.679)\end{array}$ & $\begin{array}{l}1.88 \pm 0.091 \\
(1.29,2.566)\end{array}$ & $\begin{array}{l}0.335 \pm 0.014 \\
(0.268,0.413)\end{array}$ & $\begin{array}{c}5,274,897.467 \pm 31,001.001 \\
\quad(5,109,498,5,437,036)\end{array}$ \\
\hline New & $\begin{array}{l}95 \% \text { CI for mean } \\
\text { Range }\end{array}$ & $\begin{array}{l}0.972 \pm 0.002 \\
(0.952,0.981)\end{array}$ & $\begin{array}{l}24.654 \pm 1.371 \\
(17.79,30.741)\end{array}$ & $\begin{array}{l}0.99 \pm 0.168 \\
(0.155,1.698)\end{array}$ & $\begin{array}{l}0.248 \pm 0.03 \\
(0.06,0.357)\end{array}$ & $\begin{array}{c}5,681,484.9 \pm 22,070.087 \\
(5,527,098,5,777,804)\end{array}$ \\
\hline
\end{tabular}

Table A5. KPI statistics of big dyeing manufacturer.

\begin{tabular}{|c|c|c|c|c|c|c|}
\hline Model & Statistics Item & $\begin{array}{l}\text { Average Facility } \\
\text { Utilization }\end{array}$ & $\begin{array}{l}\text { Average Lead } \\
\text { Time (Days) }\end{array}$ & $\begin{array}{l}\text { Average Unit } \\
\text { Cost (CNY) }\end{array}$ & $\begin{array}{l}\text { Delayed Order } \\
\text { Percentage }\end{array}$ & Total Yield (m) \\
\hline Traditional & $\begin{array}{l}\text { 95\% CI for mean } \\
\text { Range }\end{array}$ & $\begin{array}{c}0.934 \pm 0.003 \\
(0.91,0.944)\end{array}$ & $\begin{array}{c}66.154 \pm 2.233 \\
(50.092,73.768)\end{array}$ & $\begin{array}{c}1.901 \pm 0.135 \\
(3.14,4.406)\end{array}$ & $\begin{array}{c}0.537 \pm 0.024 \\
(0.364,0.611)\end{array}$ & $\begin{array}{c}338,324.267 \pm 1828.138 \\
(324,216,345,194)\end{array}$ \\
\hline Outsource & $\begin{array}{l}\text { 95\% CI for mean } \\
\text { Range }\end{array}$ & $\begin{array}{l}0.833 \pm 0.019 \\
(0.752,0.968)\end{array}$ & $\begin{array}{c}35.65 \pm 3.742 \\
(19.004,53.611)\end{array}$ & $\begin{array}{l}0.213 \pm 0.164 \\
(0.194,0.324)\end{array}$ & $\begin{array}{c}0.223 \pm 0.073 \\
(0,0.476)\end{array}$ & $\begin{array}{c}283,500.433 \pm 10,350.579 \\
(240,902,363,864)\end{array}$ \\
\hline New & $\begin{array}{l}\text { 95\% CI for mean } \\
\text { Range }\end{array}$ & $\begin{array}{l}0.955 \pm 0.005 \\
(0.927,0.979)\end{array}$ & $\begin{array}{l}59.416 \pm 2.685 \\
(36.278,69.873)\end{array}$ & $\begin{array}{l}1.036 \pm 0.111 \\
(0.262,1.576)\end{array}$ & $\begin{array}{l}0.515 \pm 0.025 \\
(0.239,0.587)\end{array}$ & $\begin{array}{c}353,250.067 \pm 2952.141 \\
(336,762,371,446)\end{array}$ \\
\hline
\end{tabular}

Table A6. KPI statistics of dyeing SMEs

\begin{tabular}{ccccccc}
\hline \multirow{2}{*}{ Model } & Statistics Item & $\begin{array}{c}\text { Average Facility } \\
\text { Utilization }\end{array}$ & $\begin{array}{c}\text { Average Lead } \\
\text { Time (Days) }\end{array}$ & $\begin{array}{c}\text { Average Unit } \\
\text { Cost (CNY) }\end{array}$ & $\begin{array}{c}\text { Delayed Order } \\
\text { Percentage }\end{array}$ & $\begin{array}{c}\text { Total Yield (m) } \\
\text { Traditional }\end{array}$ \\
& 95\% CI for mean & $0.927 \pm 0.003$ & $29.253 \pm 0.702$ & $1.973 \pm 0.082$ & $0.331 \pm 0.012$ & $4,899,543.3 \pm 25,464.648$ \\
& Range & $(0.911,0.945)$ & $(24.92,34.744)$ & $(1.541,2.682)$ & $(0.262,0.435)$ & $(4,812,848,5079,448)$ \\
\hline \multirow{2}{*}{ Outsource } & $95 \%$ CI for mean & $0.936 \pm 0.004$ & $29.705 \pm 0.81$ & $1.914 \pm 0.091$ & $0.338 \pm 0.013$ & $4,991,397.033 \pm 32,673.74$ \\
& Range & $(0.901,0.956)$ & $(25.272,34.381)$ & $(1.32,2.609)$ & $(0.273,0.412)$ & $(4,991,397.033,5,138,218)$ \\
\hline \multirow{2}{*}{ New } & $95 \%$ CI for mean & $0.972 \pm 0.002$ & $23.944 \pm 1.368$ & $0.989 \pm 0.17$ & $0.241 \pm 0.03$ & $5,328,234.833 \pm 20,178.224$ \\
& Range & $(0.952,0.981)$ & $(17.098,29.954)$ & $(0.153,1.701)$ & $(0.046,0.352)$ & $(5,190,336,5,414,682)$ \\
\hline
\end{tabular}




\section{References}

1. Meisel, F.; Bierwirth, C. The design of Make-to-Order supply networks under uncertainties using simulation and optimisation. Int. J. Prod. Res. 2014, 52, 6590-6607. [CrossRef]

2. Olhager, J.; Östlund, B. An integrated push-pull manufacturing strategy. Eur. J. Oper. Res. 1990, 45, 135-142. [CrossRef]

3. Ioannou, G.; Dimitriou, S. Lead time estimation in MRP/ERP for make-to-order manufacturing systems. Int. J. Prod. Econ. 2012, 139, 551-563. [CrossRef]

4. Morikawa, K.; Takahashi, K.; Hirotani, D. Make-to-stock policies for a multistage serial system under a make-to-order production environment. Int. J. Prod. Econ. 2014, 147, 30-37. [CrossRef]

5. Chen, J.M.; Cheng, H.L.; Lin, I.C. On channel coordination under price-dependent revenue-sharing: Can eBay's fee structure coordinate the channel? J. Oper. Res. Soc. 2011, 62, 1992-2001. [CrossRef]

6. Hu, B.Y.; Feng, Y. Optimization and coordination of supply chain with revenue sharing contracts and service requirement under supply and demand uncertainty. Int. J. Prod. Econ. 2017, 183, 185-193. [CrossRef]

7. Arani, H.V.; Rabbani, M.; Rafiei, H. A revenue-sharing option contract toward coordination of supply chains. Int. J. Prod. Econ. 2016, 178, 42-56. [CrossRef]

8. Han, G.H.; Dong, M. Trust-embedded coordination in supply chain information sharing. Int. J. Prod. Res. 2015, 53, 5624-5639. [CrossRef]

9. Khan, M.; Hussain, M.; Saber, H.M. Information sharing in a sustainable supply chain. Int. J. Prod. Econ. 2016, 181, 208-214. [CrossRef]

10. Kim, M.; Chai, S. The impact of supplier innovativeness, information sharing and strategic sourcing on improving supply chain agility: Global supply chain perspective. Int. J. Prod. Econ. 2017, 187, 42-52. [CrossRef]

11. Buijs, P.; Wortmann, J.C. Joint operational decision-making in collaborative transportation networks: The role of IT. Supply Chain Manag. Int. J. 2014, 19, 200-210. [CrossRef]

12. Biehl, M.; Cook, W.; Johnston, D.A. The efficiency of joint decision making in buyer-supplier relationships. Ann. Oper. Res. 2006, 145, 15-34. [CrossRef]

13. Ayadi, O.; Cheikhrouhou, N.; Masmoudi, F. A decision support system assessing the trust level in supply chains based on information sharing dimensions. Comput. Ind. Eng. 2013, 66, 242-257. [CrossRef]

14. Nayak, A.; Levalle, R.R.; Lee, S.; Nof, S.Y. Resource sharing in cyber-physical systems: Modelling framework and case studies. Int. J. Prod. Res. 2016, 54, 6969-6983. [CrossRef]

15. Jalili Marand, A.; Li, H.; Thorstenson, A. Joint inventory control and pricing in a service-inventory system. Int. J. Prod. Econ. 2017, in press. [CrossRef]

16. Samaddar, S.; Rabinowitz, G.; Mehrez, A. Resource sharing and scheduling for cyclic production in a computer-integrated manufacturing cell. Comput. Ind. Eng. 1999, 36, 525-547. [CrossRef]

17. $\mathrm{Xu}, \mathrm{X}$. From cloud computing to cloud manufacturing. Robot. Comput. Integr. Manuf. 2012, 28, 75-86. [CrossRef]

18. Zhang, L.; Luo, Y.; Tao, F.; Li, B.H.; Ren, L.; Zhang, X. Cloud manufacturing: A new manufacturing paradigm. Enterp. Inf. Syst. 2014, 8, 167-187. [CrossRef]

19. Zhang, Y.; Zhang, G.; Qu, T.; Liu, Y.; Zhong, R.Y. Analytical target cascading for optimal configuration of cloud manufacturing services. J. Clean. Prod. 2017, 151, 330-343. [CrossRef]

20. Tanrisever, F.; Morrice, D.; Morton, D. Managing capacity flexibility in make-to-order production environments. Eur. J. Oper. Res. 2012, 216, 334-345. [CrossRef]

21. Thürer, M.; Stevenson, M.; Silva, C.; Land, M.J.; Fredendall, L.D.; Melnyk, S.A. Lean control for make-to-order companies: Integrating customer enquiry management and order release. Prod. Oper. Manag. 2014, 23, 463-476. [CrossRef]

22. Pascual, R.; Godoy, D.; Figueroa, H. Optimizing maintenance service contracts under imperfect maintenance and a finite time horizon. Appl. Stoch. Model. Bus. Ind. 2013, 29, 564-577. [CrossRef]

23. Keiser, S.; Garner, M. Beyond Design: The Synergy of Apparel Product Development; Black, A.C., Ed.; Fairchild Books, an Imprint of Bloomsbury Publishing Inc.: New York, NY, USA, 2012.

24. Liu, Z.; Nagurney, A. Supply Chain Networks with Global Outsourcing and Quick-Response Production under Demand and Cost Uncertainty. Ann. Oper. Res. 2013, 208, 251-289. [CrossRef] 
25. Caniato, F.; Crippa, L.; Pero, M.; Sianesi, A.; Spina, G. Internationalisation and outsourcing of operations and product development in the fashion industry. Prod. Plan. Control 2015, 26, 706-722. [CrossRef]

26. Reaidy, P.J.; Gunasekaran, A.; Spalanzani, A. Bottom-up approach based on Internet of Things for order fulfillment in a collaborative warehousing environment. Int. J. Prod. Econ. 2015, 159, 29-40. [CrossRef]

27. Zhou, L.; Chong, A.Y.L.; Ngai, E.W.T. Supply chain management in the era of the internet of things. Int. J. Prod. Econ. 2015, 159, 1-3. [CrossRef]

28. Yan, B.; Yan, C.; Ke, C.; Tan, X. Information Sharing in Supply Chain of Agricultural Products Based on the Internet of Things. Available online: http:/ / dx.doi.org.lib.costello.pub.hb.se/10.1108/IMDS-12-2015-0512 (accessed on 29 November 2017).

29. Ge, H.; Gray, R.; Nolan, J. Agricultural supply chain optimization and complexity: A comparison of analytic vs simulated solutions and policies. Int. J. Prod. Econ. 2015, 159, 208-220. [CrossRef]

30. Long, Q. Distributed supply chain network modelling and simulation: Integration of agent-based distributed simulation and improved SCOR model. Int. J. Prod. Res. 2014, 52, 6899-6917. [CrossRef]

31. Akanle, O.M.; Zhang, D.Z. Agent-based model for optimising supply-chain configurations. Int. J. Prod. Econ. 2008, 115, 444-460. [CrossRef]

32. Huang, J.; Song, J. Optimal inventory control with sequential online auction in agriculture supply chain: An agent-based simulation optimisation approach. Int. J. Prod. Res. 2017. [CrossRef]

33. Pan, A.; Choi, T.M. An agent-based negotiation model on price and delivery date in a fashion supply chain. Ann. Oper. Res. 2016, 242, 529-557. [CrossRef]

34. Garcia-Flores, R.; Wang, X.Z. A multi-agent system for chemical supply chain simulation and management support. OR Spectr. 2002, 24, 343-370. [CrossRef]

(C) 2017 by the authors. Licensee MDPI, Basel, Switzerland. This article is an open access article distributed under the terms and conditions of the Creative Commons Attribution (CC BY) license (http://creativecommons.org/licenses/by/4.0/). 